PRACE NAUKOWE UNIWERSYTETU EKONOMICZNEGO WE WROCLAWIU

\title{
Dominika Kordela
}

Uniwersytet Szczeciński

e-mail: dominika.kordela@wzieu.pl

\section{CROWDFUNDING NIERUCHOMOŚCI PRZYKLADEM ROZWOJU FINANSOWANIA SPOLECZNOŚCIOWEGO}

\section{REAL ESTATE CROWDFUNDING AS AN EXAMPLE OF SOCIAL FINANCING}

DOI: $10.15611 / \mathrm{pn} .2017 .478 .23$

JEL Classification: G21, G23, E22

Streszczenie: Technologie informatyczne wykorzystywane są przez pośredników finansowych do promocji i dystrybucji usług bankowych, maklerskich czy ubezpieczeniowych. Wzrost znaczenia komunikacji wirtualnej skutkuje kolejnymi zmianami, zawieranie transakcji finansowych przez uczestników sieci Internet dzięki crowdfundingowi możliwe jest bez pośrednictwa instytucji finansowych. Relatywnie nowym sposobem finansowania i inwestowania na rynku nieruchomości jest Real Estate Crowdfunding (RECF), czyli crowdfunding nieruchomości. W artykule podjęto próbę systematyki crowdfundingu nieruchomości i umiejscowienia tego sposobu finansowania oraz inwestowania na wirtualnym rynku usług finansowych w ramach tzw. ekonomii thumu. Przedstawiono modele crowdfundingu nieruchomości oraz charakterystykę inwestycji RECF, jak również zalety i wady tego sposobu finansowania i inwestowania. Główną metodą badawczą wykorzystaną do realizacji celu jest krytyczna analiza literatury przedmiotu oraz metoda opisowa.

Slowa kluczowe: finanse, finansowanie społecznościowe, crowdfunding.

Summary: Information technology has been used by financial intermediaries for the promotion and distribution of banking services, brokerage and insurance. The growing importance of virtual communication results in amendments, for example thanks to crowdfunding financial transactions are possible without the intermediation of financial institutions. A quite new method of financing and investing is Real Estate Crowdfunding. The article focuses on types of RECF and presents the location of this method of financing and investing in the virtual market for financial services in the framework of the crowd economy. The paper presents models of real estate crowdfunding and its characteristics, as well as its advantages and disadvantages. The main research method is a critical analysis of literature and descriptive method.

Keywords: finance, social financing, crowdfunding. 


\section{Wstęp}

Rozwój technologii informatycznych skutkuje również zmianami w obszarze finansów. Pierwszym etapem zmian było stworzenie przez pośredników finansowych nowego internetowego kanału dystrybucji usług bankowych, maklerskich i ubezpieczeniowych. Od kilku lat obserwować możemy kolejny etap zmian w usługach finansowych, mianowicie zawieranie transakcji finansowych przez uczestników sieci Internet bez pośrednictwa wyspecjalizowanych pośredników. Taki sposób finansowania zyskuje na popularności w wyniku:

- rozwoju technologii informatycznych,

- wzrostu znaczenia komunikacji wirtualnej,

- spadku zaufania do instytucji finansowych po ostatnim kryzysie finansowym,

- zaostrzenia warunków udzielania kredytów.

W kontekście pozyskiwania środków finansowych na wyspecjalizowanych internetowych platformach pojawia się wiele terminów i określeń: ekonomia thumu, crowdfunding, finansowanie społecznościowe, finansowanie alternatywne. Finansowane są zarówno drobne indywidualne inicjatywy artystyczne, społeczne, sportowe, akcje charytatywne itd., jak i większe przedsięwzięcia. Również przedsiębiorstwa korzystają z zasileń kapitałowych na platformach crowdfundingowych, sprzedając za ich pośrednictwem papiery wartościowe. Kolejnym relatywnie nowym sposobem finansowania i inwestowania $\mathrm{z}$ wykorzystaniem wyspecjalizowanych portali internetowych jest real estate crowdfunding (RECF), czyli crowdfunding nieruchomości.

$\mathrm{W}$ artykule podjęto próbę systematyki crowdfundingu nieruchomości i umiejscowienia tego sposobu finansowania oraz inwestowania na wirtualnym rynku usług finansowych $\mathrm{w}$ ramach tzw. ekonomii thumu. W artykule przedstawiono modele crowdfundingu nieruchomości oraz charakterystykę inwestycji RECF, jak również zalety i wady tego sposobu finansowania i inwestowania.

\section{Crowdsourcing, crowdfunding, finansowanie tlumu, finansowanie alternatywne}

Można uznać, że źródłem tzw. ekonomii thumu (crowd economy, niem. Schwarmökonomie) jest crowdsourcing [Vassallo 2017, s. XVI-XXI]. Termin ten po raz pierwszy został użyty w 2006 r. przez Jeffa Howe'a, dziennikarza magazynu „Wired”, który zdefiniował go jako „outsourcing zadań wykonywanych tradycyjnie przez wyspecjalizowany podmiot (pracownika) do niezdefiniowanej, zwykle szerokiej grupy ludzi w formie otwartego zaproszenia". Szeroki zakres definicyjny crowdsourcingu ujętego w szersze ramy ekonomii thumu zaproponował S. Moffitt [2015]. Wyróżnił mianowicie 14 obszarów segmentów ekonomii thumu, które łączy zaangażowanie użytkowników Internetu dzięki rozwiązaniom technologicznym w postaci różnych platform internetowych. 


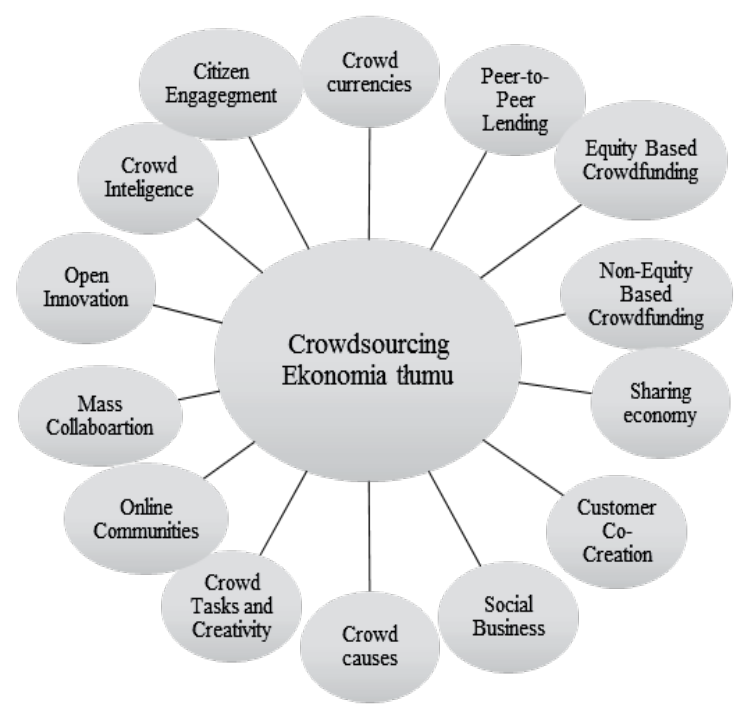

Rys. 1. Zakres i formy crowdsourcingu

Źródło: [Moffitt 2015].

Z wymienionych przez Moffitta obszarów crowdsourcingu - z uwagi na tematykę artykułu - na uwagę zasługują: Non-Equity Based Crowdfunding oraz Equity-Based Crowdfunding, czyli sposoby finansowania udziałowego i nieudziałowego za pośrednictwem wyspecjalizowanych platform internetowych. Szerokorozumiany crowdfunding wywodzi się więc od crowdsourcingu i mieści się w obszarze ekonomii tłumu.

Sam crowdfunding bywa określany mianem finansowania społecznościowego. Należy wspomnieć, że na gruncie polskim używanie terminu finansowanie społecznościowe w odniesieniu do crowdfundingu spotyka się z krytyką. Pojęcie ,społeczność" bowiem uważane jest za znaczeniowo szersze niż tłum [Malinowski, Gięłzak 2015 , s. 7]. Jednak w piśmiennictwie anglojęzycznym, w tym w dokumentach Komisji Europejskiej, crowdfunding rozumiany jest jako synonim finansowania społecznościowego [KE 2015].

W kontekście crowdfundingu pojawia się też określenie alternatywnego instrumentu finansowania, ponieważ charakteryzuje się następującymi cechami [Klimontowicz, Harasim 2015, s. 228-229]:

- sposób i miejsce dokonywania transakcji, którym są różnego rodzaju platformy transakcyjne;

- proste i przejrzyste procedury zawierania transakcji finansowych;

- brak ograniczeń regulacyjnych charakterystycznych dla sektora finansowego, w tym szczególnie sektora bankowego;

- brak ochrony uczestników transakcji kupna-sprzedaży. 
Podsumowując rozważania semantyczne, crowdfunding będący jednym z obszarów crowdsourcingu zaliczyć można do alternatywnych instrumentów finansowania, posiada on także cechy finansowania społecznościowego.

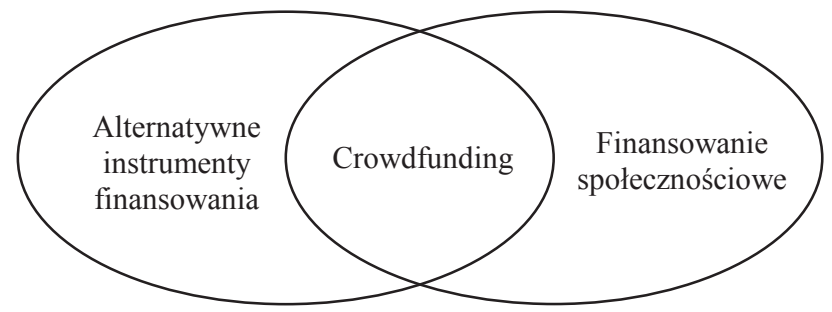

Rys. 2. Obszar znaczeniowy pojęcia crowdfunding

Źródło: opracowanie własne.

Crowdfunding w literaturze jest definiowany jako zbieranie środków finansowych na różnorodne projekty wśród internetowej społeczności. Zamieszczane na platformach internetowych oferty trafiają do nieograniczonej grupy inwestorów, a każdy z nich przekazuje według uznania sumy pieniężne o relatywnie niskiej wartości [Belleflamme i in. 2013, s. 588]. Crowdfunding bywa również określany jako termin ,parasolowy”, obejmujący znaczeniowo użycie małych kwot pieniędzy, pozyskiwanych od dużej liczby osób lub organizacji na sfinansowanie projektu, przedsięwzięcia lub pożyczki za pośrednictwem internetowych platform [Kirby, Worner 2014, s. 4]. Można więc uznać, że crowdfunding ułatwia finansowanie podmiotom mającym zapotrzebowanie na kapitał, a podmiotom mających wolne środki finansowe oferuje nowe możliwości inwestycyjne.

\section{Crowdfunding a inne formy inwestowania w nieruchomości}

Podmioty działające na rynku nieruchomości, podobnie jak podmioty działające na rynku finansowym, podejmują decyzje dotyczące czterech obszarów: inwestowania, finansowani, wyceny i zarządzania ryzykiem [Jajuga, Jajuga 2008, s. 376-377]. Wskazuje się, że inwestycje w nieruchomości powinny być częścią dobrze zdywersyfikowanego portfela inwestycyjnego. Do innych zalet inwestowania w tę grupę aktywów zaliczyć można: ochronę kapitału, regularny dochód z wynajmu oraz ochronę przed inflacją [Goins 2014, s. 3].

Istnieją dwa tradycyjne sposoby inwestowania w nieruchomości: bezpośredni i pośredni. Bezpośrednie inwestycje umożliwiają inwestorowi pełną kontrolę nad nieruchomością, jak również charakteryzują się transparentnością inwestycji; poza tym trafione inwestycje w nieruchomości mają bardzo wysokie stopy zwrotu. W przypadku bezpośrednich inwestycji w nieruchomości wymagana jest jednak wysoka wartość wolnych środków finansowych. 
Ze względu na wysoką minimalną wartość inwestycji, wysokie koszty transakcyjne oraz koszty operacyjne inwestycje w nieruchomości są domeną bogatych inwestorów. Drobni inwestorzy, osoby fizyczne dysponujące raczej ograniczonymi środkami mają trudności z dostępem do bezpośrednich inwestycji w nieruchomości. Alternatywą dla mniej zamożnych inwestorów mogą być tzw. REITs (Real Estate Investment Trust ${ }^{1}$, dzięki bowiem relatywnie niskimi minimalnym progom inwestycji oferują dostęp szerszej grupie inwestorów. Jednak inwestując w REITs, inwestorzy mają ograniczone możliwości wpływu na jakość zakupywanych nieruchomości. Poza tym koszty związane z zarządzaniem funduszami i koszty transakcyjne są relatywnie wysokie, co wpływa na obniżenie stóp zwrotu [Goins 2014, s. 4].

Inwestycyjne możliwości drobnych i nieakredytowanych inwestorów na rynku nieruchomości pozostają bardzo ograniczone. Zwykle jedyną inwestycję stanowi zamieszkiwana nieruchomość, której wartość jest często znaczącą częścią całego majątku. Pomijając aspekty związane z wartością inwestycji, bezpośrednie inwestycje w nieruchomości wymagają aktywnego zarządzania, charakteryzują się niską płynnością i związane są z wysokimi kosztami transakcyjnymi.

W Stanach Zjednoczonych dostęp do rynku nieruchomości blokowały również regulacje prawne, w pewnym zakresie dyskryminujące podmioty dysponujące relatywnie niewielkimi środkami finansowymi. Nowe regulacje prawne ${ }^{2}$, uchwalone m.in. ze względu na rozwój crowdfundingu, zmieniły nierówne traktowanie inwestorów instytucjonalnych, indywidualnych, tzw. akredytowanych i drobnych inwestorów indywidulanych, tzw. nieakredytowanych ${ }^{3}$ [Schweizer, Zhou 2016, s. 1].

W kontekście wyżej wymienionych cech bezpośredniego inwestowania w nieruchomości zaletą crowdfundingu nieruchomości jest nie tylko ułatwienie dostępu, ale również oferowany przez platformy dostęp do szczegółowych informacji dotyczących dewelopera i projektu [Schweizer, Zhou 2016, s. 10-11]. Z kolei w porównaniu do inwestowania w REITs, crowdfunding ma tę zaletę, że inwestuje się bezpośrednio w konkretną nieruchomość, a nie w fundusz, na którego portfel inwestor nie ma wpływu.

Crowdfunding nieruchomości stał się więc sposobem na otwarcie rynku nieruchomości dla szerszego grona inwestorów. Pierwsza platforma crowdfundingu nieruchomości została utworzona w roku 2010 [Goins 2014, s. 4]. Istota crowdfundingu nieruchomości polega na promocji projektów (ofert inwestycyjnych) na wyspecjalizowanej platformie, z których to projektów inwestorzy wybierają te spełniające ich kryteria. Pierwszą definicję crowdfundingu nieruchomości na gruncie rozważań aka-

${ }^{1}$ Fundusze inwestycyjne, lokujące aktywa w sposób bezpośredni i pośredni w nieruchomości, często są zwolnione z części obciążeń podatkowych

2 Pakiet ustaw The Jumpstart Our Business Startups Act (JOBS) zatwierdzony przez prezydenta Stanów Zjednoczonych Baracka Obamę w kwietniu 2012 r. [www.sec.gov].

${ }^{3}$ Nieakredytowany inwestor (Non-Accredited Investor) to według Regulacji D amerykańskiego nadzorcy SEC to inwestor indywidualny posiadający majątek netto warty mniej niż $1 \mathrm{mln}$ USD i zarobki poniżej 200 tys. USD rocznie (300 tys. rocznie dla małżeństwa) w ostatnich dwóch latach. 
demickich sformułowali Schweizer i Zhou [2016, s. 7]: „Crowdfunding nieruchomości jest formą finansowania, w której deweloper inicjujący projekt na rynku nieruchomości za pośrednictwem wyspecjalizowanej platformy internetowej przedstawia ofertę sprzedaży instrumentów udziałowych lub dłużnych w przedsiębiorstwie lub projekcie, w celu przyciągnięcia, zachęcenia dużej grupy inwestorów".

Przedmiotem inwestycji $\mathrm{w}$ transakcjach crowdfundingu nieruchomości mogą być:

- Nieruchomości komercyjne (biura, budynki i nieruchomości przemysłowe) w przypadku tych nieruchomości inwestor może liczyć na regularne roczne wpływy z wynajmu nieruchomości.

- Nieruchomości mieszkaniowe - zwykle są to apartamenty w centrach miast i nieruchomości w kurortach wakacyjnych.

- Nieruchomości gruntowe - kupowanie nieruchomości przed wybudowaniem, na tzw. przeddeweloperskim etapie.

- Kupno nieruchomości do remontu - z inwestycją $\mathrm{w}$ tego typu nieruchomości związany jest zwykle niższy poziom ryzyka, istotą inwestycji jest bowiem zmiana celu jej przeznaczenia lub jej remont.

\section{Modele crowdfundingu nieruchomości}

Praktyka gospodarka wykształciła trzy opisane w literaturze modele crowdfundingu:

1. Model donacyjny - w ramach działań w tym modelu wspierane są akcje pomocy chorym, ale również projekty artystyczne, sportowe, wydarzenia kulturalne czy akcje społeczne. W tradycyjnym modelu osoby przekazujące środki finansowe nie otrzymują gratyfikacji. Wyróżnia się również model zmodyfikowany [Dziuba 2012, s. 86-87], w którym darczyńcy otrzymują drobne niefinansowe wynagrodzenia za przekazane środki finansowe, np. zdjęcia, pocztówki, płyty, książki lub inną rzecz związaną z projektem.

2. Model pożyczkowy - przekazywane środki finansowe mają charakter pożyczki, która w określonym terminie powinna zostać spłacona wraz z odsetkami.

3. Model inwestycyjny - w tym modelu środki przekazywane są w zamian za udziały/akcje w przedsiębiorstwie lub obietnicę udziału w zyskach.

Platformy crowdfundingu nieruchomości wybierają jeden z trzech modeli [Goins 2014, s. 10; Schweizer, Zhou 2016, s. 6-7]:

- Udziałowy crowdfunding nieruchomości (equity) - polega na zakupie akcji lub udziałów w spółce celowej (SPV, special purpose vehicle) utworzonej w związku z zakupem nieruchomości. Spółką zarządzają menadżerowie, natomiast funkcja inwestorów jest pasywna. Udziałowcy otrzymują dochód w formie przepływów pieniężnych $\mathrm{z}$ ewentualnego wynajmu nieruchomości i/lub wzrostu wartości nieruchomości. Inwestycja może być określona czasowo lub bezterminowa; w obu przypadkach inwestor, chcąc wyjść z inwestycji, musi sprzedać posiadane akcji lub udziały na rynku nieregulowanym. 
- Dłużny crowdfunding nieruchomości $(d e b t)$ - platformy finansujące nieruchomości poprzez instrumenty dłużne działają w typowym modelu pożyczkowym. Kapitałobiorcą jest deweloper, za pożyczony kapitał płaci stałe odsetki, a w określonym terminie spłaca całą sumę. Zabezpieczeniem spłaty pożyczki jest finansowana nieruchomość.

- Model współinwestowania (co-investment) - w tym modelu grupa kapitałodawców razem inwestuje w nieruchomość. Każdy z inwestorów posiada określony udział w nieruchomości i otrzymuje związany z tym udziałem przychód z wynajmu nieruchomości. Zwykle jest to inwestycja długoterminowa.

Crowdfunding nieruchomości jest zaliczany do modelu udziałowego - jeżeli inwestorowi sprzedawane są udziały w finansowanej nieruchomości. Może być jednak również uznany za przykład modelu pożyczkowego, gdy inwestycja w nieruchomości ma charakter dłużny. Platformy internetowe, zarejestrowane i działające na najbardziej rozwiniętym obecnie rynku, w Stanach Zjednoczonych przewidują obie formy inwestycji: dłużną i udziałową jednocześnie, lub są wyspecjalizowane tylko w finansowaniu dłużnym bądź udziałowym [Vogel, Moll 2014, s. 11].

Podmiotami uczestniczącymi w transakcjach crowdfundingu nieruchomości są [Baker 2016, s. 30]:

- Główny inwestor, inicjator projektu inwestycyjnego (sponsor) - podmiot gospodarczy lub osoba fizyczna poszukująca środków na sfinansowanie inwestycji.

- Inwestorzy - osoby fizyczne kupujące udziały w inwestycji bądź pożyczające środki finansowe na realizację inwestycji w nieruchomości.

- Wyspecjalizowana platforma internetowa będąca pośrednikiem między inicjatorem projektu a inwestorami.

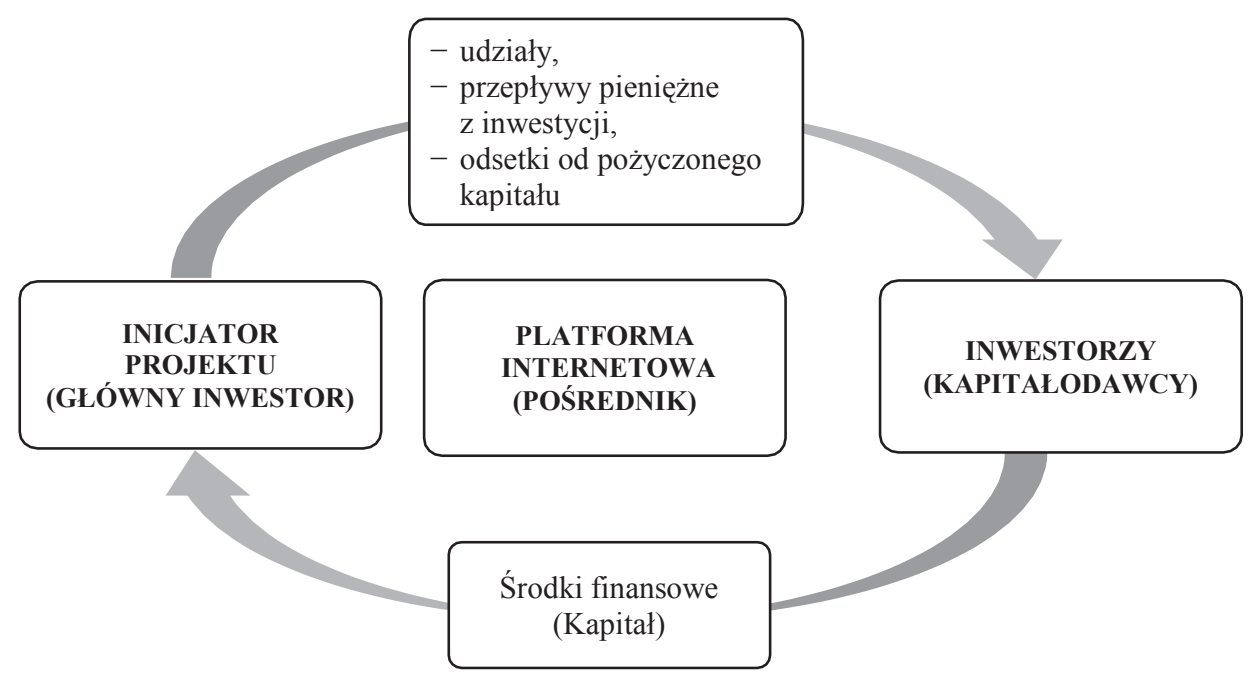

Rys. 3. Schemat transakcji crowdfundingu nieruchomości

Źródło: opracowanie własne. 
W CFRE inicjatorem jest deweloper (w piśmiennictwie anglojęzycznym również określany jako sponsor), który poszukując kapitału, zgłasza się do wyspecjalizowanej platformy internetowej, która z kolei pełniąc funkcje pośrednika, ale również w pewnym zakresie gwaranta, dokonuje due dilligence i po akceptacji umieszcza projekt na stronie internetowej. Opis projektu zawiera zwykle informacje o inicjatorze (w tym jego dokonania), szczegółowe dane nieruchomości, analizę rynku, historyczne dane finansowe, założenia inwestycyjne, opis czynników ryzyka oraz strategie wyjścia z inwestycji [Schweizer, Zhou 2016, s. 7].

Platformy crowdfundingu nieruchomości dają inwestorom możliwość wyboru wielu rodzajów nieruchomości, w tym prywatnych, komercyjnych, różniących się między sobą lokalizacją, przewidywaną stopą zwrotu, zakresem czasowym inwestycji. Na świecie przyjmuje się różne modele, a także różny zakres regulacji crowdfundingu nieruchomości. Zwykle funkcja platformy crowdfundingowej ograniczona jest do prezentacji ofert oraz kontaktowaniu potencjalnych inwestorów z deweloperami. Platformy nie zbierają środków finansowych od inwestorów, nie ponoszą również odpowiedzialności za powodzenie inwestycji, choć mogą dokonywać ocen deweloperów lub samych inwestycji. Dochodem platform są opłaty pobierane od deweloperów, a czasem również od potencjalnych inwestorów.

\section{Poziom i charakter rozwoju crowdfundingu nieruchomości}

Rynek crowdfundingu nieruchomości ze względu na jego początkowe stadium rozwoju nie został jeszcze szeroko opisany ani przebadany. Istotnej wartości poznawczej dostarczają raporty S. Goins [2014] oraz Massolution [2015], a także wyniki pierwszych szerokich badań dotyczących RECF przeprowadzonych przez Schweizera i Zhou [2016].

W swoim raporcie Massolution podaje, że w roku 2014 wartość crowdfundingu nieruchomości wzrosła o 156\% i wyniosła ponad 1 mld USD; jednocześnie określono szacunkowy wzrost w roku 2015 do 2,5 mld USD. Dane z roku 2014 wskazują, że największym rynkiem RECF jest Ameryka Północna z udziałem wynoszącym $56 \%$, udział europejskiego rynku wynosił 42\% [Massolution 2015]. RECF był najszybciej rozwijającym się segmentem crowdfundingu w 2015 r. [Hogue 2016].

Wyniki badań przeprowadzonych przez Schweizera i Zhou [2016] wskazują, że:

- Projekty finansowane w modelu udziałowym charakteryzują się wyższą stopą zwrotu niż projekty finansowane w modelu dłużnym.

- Prywatni inicjatorzy projektów, z ograniczonym doświadczeniem i osiągnięciami, chętniej korzystają z zasileń o charakterze dłużnym (aż 92\%), natomiast instytucjonalni inwestorzy częściej pozyskują kapitał udziałowy (60\%).

- Inwestycje w instrumenty dłużne charakteryzują się krótszymi terminami niż inwestycje w instrumenty udziałowe.

Z kolei Goins [2014, s. 12] wskazuje w raporcie, że w 2014 r. 40\% projektów finansowych w ramach RECF pozyskała kapitał dłużny, 38\% kapitał udziałowy, 
a $23 \%$ przyjęło model współinwestowania. $57 \%$ wszystkich inwestycji to były nieruchomości mieszkaniowe, 26\% komercyjne, a 17\% nieruchomości o różnym przeznaczeniu.

W modelu udziałowym średnia wartość inwestycji wynosiła 25600 USD, natomiast w modelu dłużnym zdecydowanie mniej, mianowicie 7000 USD (tab. 1).

Tabela 1. Poziom inwestycji w projektach crowdfundingu nieruchomości w USD

\begin{tabular}{|l|c|c|}
\cline { 2 - 3 } \multicolumn{1}{c|}{} & Model udziałowy & Model dhużny \\
\hline Minimalna wartość inwestycji & 5000 & 1000 \\
\hline Średnia wartość inwestycji & 25600 & 7000 \\
\hline Maksymalna wartość inwestycji & 250000 & 8400 \\
\hline
\end{tabular}

Źródło: opracowanie własne na podstawie [Goins 2014].

Średni termin inwestycji w przypadku instrumentów udziałowych jest dłuższy i wynosi 4 lata, natomiast inwestycje w instrumenty dłużne charakteryzują się krótszym czasem, średnio 1,5 roku (tab. 2).

Tabela 2. Podstawowe cechy inwestycji dłużnych i udziałowych crowdfundingu nieruchomości

\begin{tabular}{|l|c|c|}
\cline { 2 - 3 } \multicolumn{1}{c|}{} & Model udziałowy & Model dhużny \\
\hline Średni termin inwestycji & 4 lata & 1,5 roku \\
\hline Stopa zwrotu z inwestycji & $18 \%$ & $14,25 \%$ \\
\hline
\end{tabular}

Źródło: opracowanie własne na podstawie [Goins 2014].

Analiza i ocena projektów realizowanych w ramach crowdfundingu nieruchomości, a także samego sposobu finansowania wskazuje na zalety i wady zarówno dla inwestorów, jak i dewelopera poszukującego kapitału na realizację projektu. Zalety crowdfundingu nieruchomości [Vogel, Moll 2014, s. 8-10; Goins 2014, s. 4]:

- Niskie bariery wejścia dla inwestorów.

- Szeroki wybór potencjalnych inwestycji.

- Przejrzyste informacje o strukturze kosztów związanych z inwestycją.

- Informacje o oczekiwanej stopie zwrotu z inwestycji.

- Możliwość obniżania wartości pojedynczej inwestycji dzięki udziałowi wielu inwestorów, niskie bariery wejścia.

- Dla głównego inwestora (inicjatora zbiórki) koszty pozyskania kapitału są niższe niż przypadku RETIS.

- W perspektywie możliwa ocena głównego inwestora (inicjatora zbiórki), dzięki czemu można będzie wybierać projekty wiarygodnych partnerów jako przedmiot inwestycji.

- Umożliwia inicjatorom projektu (deweloperom) szybki, tani i łatwiejszy dostęp do kapitału. 
- Koszty tego finansowania są relatywnie niskie (zwykle obowiązują opłata inicjująca za udostępnienie projektu na platformie oraz opłata administracyjna za due dilligence projektu.

Wady crowdfundingu nieruchomości:

- Eksperci wskazują, że w przypadku osób fizycznych inwestycje w indeksy, fundusze inwestycyjne dają lepsze stopy zwrotu i charakteryzują się niższym ryzykiem niż inwestycje w akcje czy nieruchomości.

- Do inwestowania w nieruchomości potrzebna jest solidna wiedza; eksperci zaprzeczają, że każdy może inwestować, nawet przy posiadaniu informacji na temat przedmiotu inwestycji dostarczanych przez platformy crowdfundingowe.

- Wskazuje się, że prezentowana szacowna stopa zwrotu może być przeszacowana.

- Brak bezpośredniego kontaktu inicjator zbiórki-inwestorzy, możliwe wystąpienie konfliktu interesów, jeśli istnieje bardzo wielu właścicieli.

\section{Zakończenie}

Crowdfunding nieruchomości rozwija się niezwykle dynamicznie. Możliwe jest to m.in. dzięki dopuszczeniu inwestowania relatywnie niewielkich kwot $\mathrm{w}$ nieruchomości o znaczącej wartości oraz możliwości uzyskania wysokiej stopy zwrotu. Rozwój tego sposobu finansowania determinowany będzie jednak ryzykiem inwestycji. Brak bezpośredniego kontaktu inicjator projektu-inwestorzy oraz wirtualny charakter transakcji powoduje wzrost ryzyka kontrahenta. $Z$ czasem może się pojawić presja inwestorów na zwiększenie zadań i odpowiedzialności samych platform. Utworzenie dedykowanych uregulowań prawnych w Stanach Zjednoczonych oraz próby tworzenia rynku wtórnego dla instrumentów emitowanych w transakcjach crowdfundingu nieruchomości wskazywać mogą na dalszy - nie tylko ilościowy, ale przede wszystkich jakościowy - rozwój tego sposobu finansowania i inwestowania.

\section{Literatura}

Baker C., 2016, Real Estate Crowdfunding - Modern Trend or Restructured Investment Model ?: Have the SEC's Proposed Rules on Crowdfunding Created a Closed-market System?, The Journal of Business, Entrepreneurship and The Law, vol. 9, issue 1.

Belleflamme P., Lambert T., Schwienbacher A., 2013, Crowfunding: Tapping the right crowd, Journal of Business Venturing, no. 29 (5).

Kirby E., Worner S., 2014, Crowd-funding: An Infant Industry Growing Fast, Staff Working Paper of the IOSCO Research Department, DWP3.

Dziuba D.T., 2012 Rozwój systemów crowdfundingu - modele, oczekiwania i uwarunkowania, Problemy Zarządzania, vol. 10, $\mathrm{nr} 3$ (38).

Goins S., 2014, Real Estate Crowdfunding. Alternative Finance Sector Report, http://www.altfi.com/ downloads/real-estate-crowdfunding-report.pdf (31.01.2017)

Hogue J., 2016, Crowdfunding 2016 Predictions: The Next real Estate Boom?, www.crowd101.com (1.12.2016). 
Howe J., 2006, The Rise of Crowdsoursing, Wired Magazin (6.01.2006).

https://www.wired.com/2006/06/crowds (20.01.2017).

Jajuga K., Jajuga T., 2008, Inwestycje. Instrumenty finansowe, aktywa niefinansowe, ryzyko finansowe, inżynieria finansowa, Wydawnictwo Naukowe PWN, Warszawa.

KE, 2015, Komisja Europejska, Zrozumieć finansowanie społecznościowe. Przewodnik dla matych $i$ średnich przedsiębiorstw, Ref. Ares (2015) 1989921 - 11/05/2015.

Klimontowicz M., Harasim J., 2015, Tendencje rozwojowe na rynku alternatywnych instrumentów finansowych, Annales Universitatis Mariae Curie-Skłodowska - Sectio H, vol. XLIX, nr 4.

Malinowski B.F., Gięłzak M., 2015, Crowdfunding. Zrealizuj swój pomyst ze wsparciem cyfrowego tlumu, Helion, Gliwice.

Massolution, 2015, CF-RE Crowdfunding for Real Estate Report, www.crowdsourcing.org (10.02.2017).

Moffitt S., 2015, 14 Parts of the Crowd Economy, http://crowdsourcingweek.com/14-parts-of-the-crowd-economy-landscape (10.02.2017).

Schweizer D., Zhou T., 2016, Do Principles Pay in Real Estate Crowdfunding?, https://papers.ssrn. com/sol3/papers2.cfm?abstract_id=2846892 (10.02.2017).

The Jumpstart Our Business Startups Act (JOBS), www.sec.gov (10.02.2017).

Vassallo W., 2017, Crowdfunding for Sustainable Entrepreneurship and Innovation, IGI Global, Hershey PA.

Vogel J.H., Moll B.S., 2014, Crowdfunding for real Estate, The Real Estate Finance Journal, Summer/ Fall. 